\title{
Immune-Induced Fever Is Mediated by IL-6 Receptors on Brain Endothelial Cells Coupled to STAT3-Dependent Induction of Brain Endothelial Prostaglandin Synthesis
}

\author{
Anna Eskilsson, ${ }^{1}$ Elahe Mirrasekhian, ${ }^{1}$ Sylvie Dufour, ${ }^{2}{ }^{\oplus}$ Markus Schwaninger, ${ }^{3}$ David Engblom, ${ }^{1}$ \\ and Anders Blomqvist ${ }^{1}$ \\ ${ }^{1}$ Division of Cell Biology, Department of Clinical and Experimental Medicine, Faculty of Health Sciences, Linköping University, S-581 85 Linköping, \\ Sweden, ${ }^{2}$ Institut Curie/CNRS UMR144, 75248 Paris, France, and ${ }^{3}$ Institute of Experimental and Clinical Pharmacology and Toxicology, University of \\ Lübeck, 23538 Lübeck, Germany
}

The cytokine IL-6, which is released upon peripheral immune challenge, is critical for the febrile response, but the mechanism by which IL-6 is pyrogenic has remained obscure. Here we generated mice with deletion of the membrane bound IL-6 receptor $\alpha$ (IL-6R $\alpha$ ) on neural cells, on peripheral nerves, on fine sensory afferent fibers, and on brain endothelial cells, respectively, and examined its role for the febrile response to peripherally injected lipopolysaccharide. We show that IL-6R $\alpha$ on neural cells, peripheral nerves, and fine sensory afferents are dispensable for the lipopolysaccharide-induced fever, whereas IL-6R $\alpha$ in the brain endothelium plays an important role. Hence deletion of IL-6R $\alpha$ on brain endothelial cells strongly attenuated the febrile response, and also led to reduced induction of the prostaglandin synthesizing enzyme Cox-2 in the hypothalamus, the temperature-regulating center in the brain, as well as reduced expression of SOCS3, suggesting involvement of the STAT signaling pathway. Furthermore, deletion of STAT3 in the brain endothelium also resulted in attenuated fever. These data show that IL-6, when endogenously released during systemic inflammation, is pyrogenic by binding to IL-6R $\alpha$ on brain endothelial cells to induce prostaglandin synthesis in these cells, probably in concerted action with other peripherally released cytokines.

Key words: blood- brain barrier; cell-specific gene deletions; fever; interleukin-6; prostaglandins; STAT3

\section{Introduction}

Fever is a hallmark of peripheral inflammation and an adaptive response to the presence of pathogenic agents (Kluger, 1991). Prostaglandin $\mathrm{E}_{2}\left(\mathrm{PGE}_{2}\right)$, acting on prostaglandin $\mathrm{E}$ receptor type $3\left(\mathrm{EP}_{3}\right)$-expressing neurons in the pre-optic area of the hypothalamus, is the principal mediator of fever (Engblom et al., 2003; Lazarus et al., 2007), and is synthesized in the presence of peripherally released cytokines with thermogenic properties, such as IL-1 and IL-6 (Conti et al., 2004). The latter has been shown to be critical for the febrile response, because mice with global deletion of the Il6 gene do not develop fever upon peripheral immune stimulation (Chai et al., 1996; Kozak et al., 1998; Nilsberth et al., 2009). However, the mechanism by which IL-6 mediates fever is not clear. Whereas studies using genetically modified animals

\footnotetext{
Received Aug. 21, 2014; revised 0ct. 9, 2014; accepted Oct. 11, 2014

Author contributions:A.E., D.E., and A.B. designed research;A.E. and E.M. performed research;S.D. and M.S. contributed unpublished reagents/analytic tools; A.E., E.M., D.E., and A.B. analyzed data; A.E., D.E., and A.B. wrote the paper.

This study was supported by the Swedish Medical Research Council (A.B. and D.E.), the Swedish Cancer Foundation (A.B.), the European Research Council (starting grant to D.E.), the Knut and Alice Wallenberg Foundation (D.E.), the Swedish Brain foundation (A.B. and D.E.), and the County Council Östergötland (A.B. and D.E).

The authors declare no competing financial interests.

Correspondence should be addressed to Dr. Anders Blomqvist, Division of Cell Biology, Department of Clinical and Experimental Medicine, Faculty of Health Sciences, Linköping University, S-581 85 Linköping, Sweden. E-mail: anders.blomqvist@liu.se.

DOI:10.1523/JNEUROSCI.3520-14.2014

Copyright $\odot 2014$ the authors $\quad 0270-6474 / 14 / 3415957-05 \$ 15.00 / 0$
}

have shown that IL-1 elicits fever by inducing $\mathrm{PGE}_{2}$ synthesis in brain endothelial cells (Ching et al., 2007; Ridder et al., 2011; Wilhelms et al., 2014), similar functional studies on the role of IL-6 for the febrile response have been lacking. Receptors for IL-6 exist in two forms, a soluble receptor, sIL-6R, and a membrane bound receptor, IL-6R $\alpha$. The latter has been shown to be expressed in the brain parenchyma, as well as in the brain microvasculature (Vallières and Rivest, 1997), but also on peripheral nerves (Gadient and Otten, 1996), and at several of these locations its expression is induced by immune challenge (Vallières and Rivest, 1997), implying that immune-induced IL-6 could act at several different sites to elicit the variety of brain responses associated with this cytokine.

Here, we examined the role of IL-6R $\alpha$ on different cell types for the generation of inflammatory fever. Using mice with floxed IL-6R $\alpha$ and tissue-specific Cre-lines we generated mice with deletion of the IL-6R $\alpha$ in sensory nerves, neural cells, and brain endothelial cells, and studied their febrile response to peripheral immune challenge. Based on the obtained results we further examined the relationship between IL-6R $\alpha$ on brain endothelial cells and the induction of the prostaglandin synthesizing enzyme cyclooxygenase (Cox)-2 and the inhibitor of the STAT3 transcription factor SOCS3 in these cells, and we examined the febrile response in mice with endothelial-specific deletion of STAT3. Our data show that IL-6, when endogenously released during 
systemic inflammation, is pyrogenic by binding to IL-6R $\alpha$ on brain endothelial cells to induce prostaglandin synthesis in these cells via the STAT3 signaling pathway.

\section{Materials and Methods}

Animals. Mice of either sex with tissue-specific deletions of IL-6R $\alpha$ were created by crossing mice possessing loxP sites flanking exons 4-6 of the IL- 6 receptor $\alpha$ chain (Il6ra; The Jackson Laboratory) with mice expressing Cre recombinase from the Nestin promoter (expressed in the central and peripheral nervous system), the endogenous Trpv1 locus (expressed by nociceptors in primary sensory ganglia, as well as by some cell groups in the hypothalamus; $\mathrm{Ca}-$ vanaugh et al., 2011; both from The Jackson Laboratory), the human tissue plasminogen activator $(\mathrm{HtPa}$; expressed by neural crest structures; Pietri et al., 2003), or a tamoxifeninducible $\mathrm{CreER}^{\mathrm{T} 2}$ from the Slcolc1 promoter (expressed in the cerebrovascular endothelium; Ridder et al., 2011). Mice with endothelialspecific deletion of the STAT3 were generated by crossing Slcolcl CreER ${ }^{T 2}$ mice with mice with loxP on the $5^{\prime}$ side of exon 18 and on the $3^{\prime}$ side of exon 20 of the Stat 3 gene (The Jackson Laboratory). The Slcolcl CreER $R^{T 2}$ line was also crossed with a Cre reporter line with a loxPflanked STOP cassette preventing transcription of a CAG promoter-driven red fluorescent protein variant (tdTomato) introduced into the Gt(ROSA)26Sor locus (The Jackson Laboratory).

The mouse strains were all held on a C57BL/6 background. Gene deletion in mice with the Slcolc1 CreER ${ }^{T 2}$ construct was induced by intraperitoneal injection of tamoxifen $(1 \mathrm{mg}$ tamoxifen diluted in a mixture of $10 \%$ ethanol and $90 \%$ sunflower seed oil twice a day for $5 \mathrm{~d}$ ) at least 5 weeks before further experiments. In each set of experiments, the mice in different subgroups were matched for sex and age. All animal experiments were approved by the Linköping Animal Care and Use Committee and followed international guidelines.

Telemetric temperature recordings. Mice were anesthetized with isoflurane (Abbot Scandinavia), implanted intraperitoneally with a transponder that records core body temperature (Mini Mitter), and then housed in a room in which the ambient temperature was set to $29^{\circ} \mathrm{C}$, providing near-thermoneutral conditions (Rudaya et al., 2005), and on a $12 \mathrm{~h}$ light/ dark cycle (light on at 7:00 A.M.). At least 1 week after the implantation of the transponder the animals were injected intraperitoneally with bacterial wall LPS from Escherichia coli (Sigma-Aldrich; O111:B4; $120 \mu \mathrm{g} / \mathrm{kg}$ body weight) diluted in $100 \mu$ l saline, or with saline only. After a washout period of 7-10 d saline-injected animals were injected with LPS as described above, and LPS-injected animals were injected with saline. One group of mice was implanted with an indwelling peritoneal catheter that was exteriorized at the back of the neck and connected to a swivel system, as described previously for intravenous catheters (Engström et al., 2012). Three days after the implantation the animals were injected with LPS or saline, as above. LPS/saline injections were done at approximately 9:00 A.M. and the recordings performed during the light-on period.

$q R T-P C R$. Mice were injected intraperitoneally with $120 \mu \mathrm{g} / \mathrm{kg} \mathrm{LPS}$ (or vehicle) and killed $3 \mathrm{~h}$ later by asphyxiation with $\mathrm{CO}_{2}$. The hypothalamus was cut out as described previously (Reyes et al., 2003), placed in RNA later stabilization reagent (Qiagen), and kept at $-70^{\circ} \mathrm{C}$ until further processing. RNA was extracted with RNeasy Universal Plus kit (Qiagen) and reverse transcription was done with High Capacity cDNA Reverse Transcription kit (Applied Biosystems). qPCR was performed using Gene Expression Master Mix (Applied Biosystems) on a 96-well plate
(7900HT Fast RT-PCR system; Applied Biosystems). TaqMan assays used were for IL6ra: Mm00439653_m1; for Ptgs2 (Cox-2): Mm00478374_m1; for Nfkbia (Iкb): Mm00477800_g1; for Socs3: Mm00545913_s1; and for GAPDH: Mm99999915_g1 (Applied Biosystems).

Immunohistochemistry. The immunohistochemical procedures were performed according to standardized protocols (Engström et al., 2012). The primary antibody was rabbit anti-Cox-2 (1:500; sc-1747 M-17; Santa Cruz Biotechnology), which was detected with Alexa Fluor 488 donkey anti-rabbit (1:500; Life Technologies).

Statistics. Statistical analyses were done in Graph Pad Prism (GraphPad Software), using a two-way ANOVA followed by Bonferroni's post hoc test for multiple comparisons. Results were considered significant when $p<0.05$.

\section{Results}

IL-6R $\alpha$ on neural cells, including sensory nerves, is dispensable for the febrile response to LPS

Both mice with deletion of IL-6R $\alpha$ in neural cells (IL-6R $\alpha^{\Delta \text { Nestin }}$ ) and their WT littermates (IL-6R $\alpha^{\mathrm{fl} / \mathrm{fl}}$ ) showed a prominent rise of their body temperature after intraperitoneal injection of LPS (120 $\mu \mathrm{g} / \mathrm{kg}$ body weight) that peaked at $\sim 5-6 \mathrm{~h}$ post injection (Fig. 1a). A similar temperature response was seen in mice with deletion of IL-6R $\alpha$ in peripheral nerves (IL-6R $\alpha^{\Delta \mathrm{HtPa}}$; Fig. $1 b$ ), as well as in mice with deletion of the IL-6R $\alpha$ in fine sensory nerves (IL-6R $\alpha^{\Delta \text { TRPV1}}$; Fig. $1 c$ ). Although there were no statistically significant differences in the temperature responses to LPS between the genetically modified animals and their WT littermates in any of the three mouse lines examined, there was in all of them a tendency to a reduced temperature response to LPS in the genetically modified mice during the first $3 \mathrm{~h}$ post injection (Fig. $1 a-c$ ), corresponding to the second phase of fever (Rudaya et al., 2005). 
a

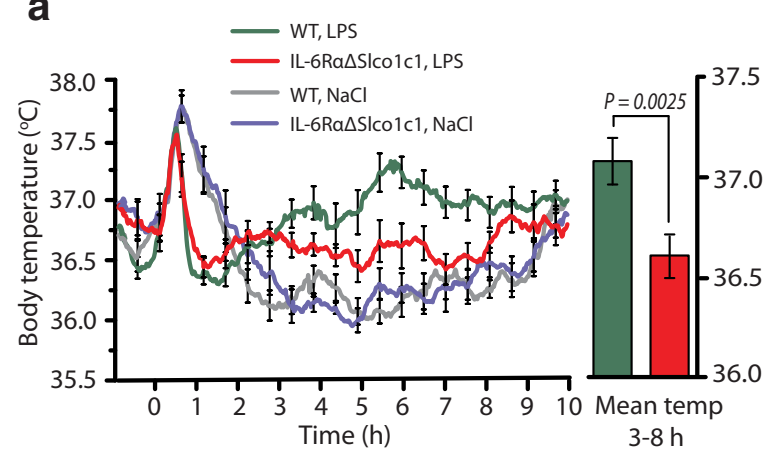

b

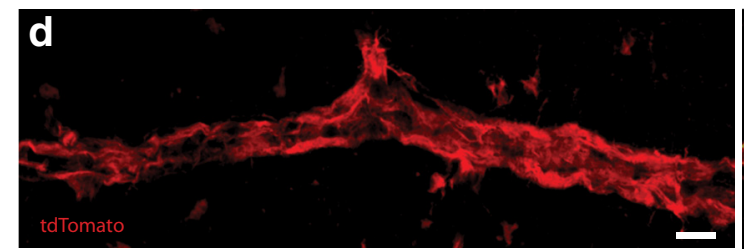

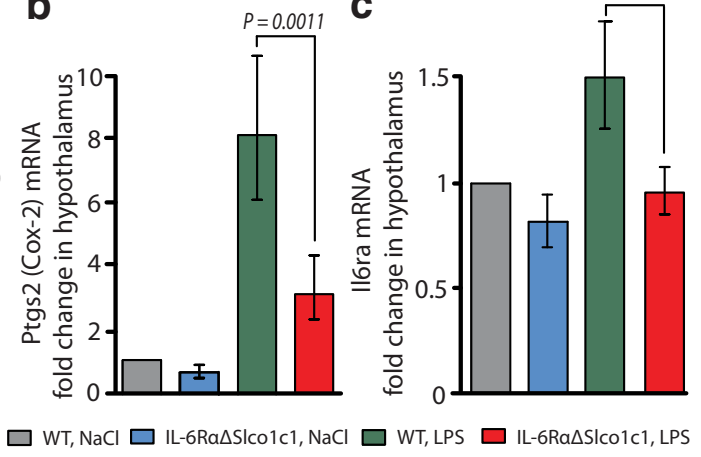

Figure 2. Deletion of IL-6R $\alpha$ on brain endothelial cells results in attenuated fever and hypothalamic Cox-2 expression. $\boldsymbol{a}$, Blunted febrile response in IL-6R $\alpha$ SIco1c1 mice to $120 \mu \mathrm{g} / \mathrm{kg}$ LPS intraperitoneally; $n=16 . \boldsymbol{b}, \boldsymbol{c}$, Attenuated induction of Ptgs2 (Cox-2; $\boldsymbol{b})$ and of $/ / 6 r \alpha(\boldsymbol{c})$ mRNA in the hypothalamus of IL-6R $\alpha^{\Delta \text { SIco } 1 \mathrm{c} 1}$ mice; $n=7-10$. $\boldsymbol{d}$, Colocalization (arrowheads) between red fluorescent reporter protein (tdTomato) and Cox-2 in the hypothalamus of Gt(ROSA)26Sor ${ }^{\Delta \text { Slco }_{1} 1}$ mice. Scale bar, $50 \mu \mathrm{m}$.

Because these early responses are difficult to properly examine in models in which the handling of the animals causes a prominent initial stress-induced hyperthermia (the rapid initial temperature peak in all traces in Fig. $1 a-c$ ), we also examined the febrile response to LPS after injection into an indwelling peritoneal catheter, whose outer end was accessible outside the animals' cage. Using this approach, in which no handling stress interfered with the body temperature recordings, no attenuation of the febrile response was seen in the genetically modified mice (Fig. 1d).

\section{Deletion of IL-6R $\alpha$ on brain endothelial cells attenuates the febrile response to LPS}

Next we examined the febrile response in mice with deletion of the IL-6R $\alpha$ in brain endothelial cells (IL-6R $\alpha^{\Delta \text { Slcolc1 }}$ ). As shown in Figure $2 a$, the genetically modified mice displayed an attenuated temperature response to intraperitoneally injected LPS compared with their WT littermates. Statistical analysis of the temperature differences during 3- $8 \mathrm{~h}$ post injection (the $8 \mathrm{~h}$ time point was chosen as cutoff because at later time points body temperature starts to rise because of increased activity of the mice in anticipation of the dark period as seen in the temperature recording from the saline-injected control mice; Fig. $2 a$ ) showed significant genotype $\left(F_{(1,60)}=6.14 ; p=0.0160\right)$, treatment $\left(F_{(1,60)}=35.51 ; p<0.0001\right)$, and interaction $\left(F_{(1,60)}=45.31 ; p=\right.$ $0.0247)$ effects. Post hoc test showed significant differences between LPS-treated IL-6R $\alpha^{\Delta \text { Slcolcl }}$ and WT mice $(p=0.0025)$.

\section{Mice with deletion of IL-6R $\alpha$ on brain endothelial cells show} reduced induction of Cox- 2 in the hypothalamus after immune challenge

We next examined if the attenuated fever in IL-6R $\alpha^{\Delta \text { Slcolc1 }}$ mice was associated with reduced induction in the hypothalamus of Cox-2, the rate-limiting enzyme for the synthesis of $\mathrm{PGE}_{2}$ ( $\mathrm{Li}$ et al., 1999; Engström Ruud et al., 2013). qPCR analysis showed that the immune-induced expression of Ptgs2 (encoding Cox-2) in the hypothalamus of IL-6R $\alpha^{\Delta \text { Slcolc1 }}$ mice was much reduced, compared with that seen in WT (IL-6R $\alpha^{\mathrm{fl} / \mathrm{fl})}$ ) littermates (Fig. $2 b$; genotype: $F_{(1,31)}=14.47, p=0.006$; treatment: $F_{(1,31)}=96.75$,

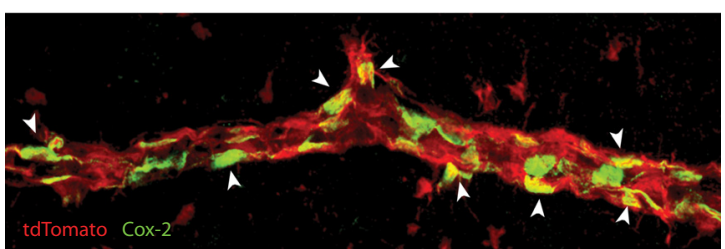

$p=0.0001$; interaction: $F_{(1,31)}=1.52, p=0.2275$; LPS IL$6 \mathrm{R} \alpha^{\Delta \text { Slcolc1 }}$ vs LPS WT: $\left.p=0.0011\right)$. The IL-6R $\alpha^{\Delta \text { Slcolc1 }}$ mice also showed reduced induction of Il6r $\alpha$, as expected (Fig. $2 c$; genotype: $F_{(1,31)}=9.16, p=0.0049$; treatment: $F_{(1,31)}=6.13, p=$ 0.0189; interaction: $F_{(1,31)}=1.28, p=0.2657$; LPS IL-6R $\alpha^{\Delta \text { Slcolc1 }}$ vs LPS WT: $p=0.0066$ ). Cox-2 is expressed by endothelial cells upon immune challenge (Cao et al., 1996; Engström et al., 2012). Cox-2 immunohistochemistry on hypothalamic sections from mice that expressed red fluorescent protein (tdTomato) in cells recombined by Slcolc1-CreER ${ }^{T 2}$ verified that Cre-induced recombination and deletion of the IL-6R $\alpha$ occurred in Cox-2expressing endothelial cells, because most of the Cox-2expressing cells also expressed tdTomato (Fig. $2 d$ ). Together, these data imply that the reduced Cox- 2 expression seen in the IL-6R $\alpha^{\Delta \text { Slcolc1 }}$ mice, is directly related to impaired IL-6R $\alpha$ activity in endothelial cells.

\section{Induction of Cox-2 by IL-6/IL-6R $\alpha$ involves the STAT3 system}

To further analyze the intracellular signaling pathway by which IL-6/IL-6R $\alpha$ induces the expression of Cox-2, we examined to what extent deletion of the IL-6R $\alpha$ in endothelial cells affected the immune-induced expression of $N f k b i a$, encoding $\mathrm{I} \kappa \mathrm{B}$, and an index of NF $\kappa$ B activation (Cheng et al., 1994), or Socs3, encoding a protein in the STAT inhibitor family (Starr et al., 1997). Whereas both IL-6R $\alpha^{\Delta \text { Slcolc1 }}$ mice and their WT littermates showed similar LPS-induced expression of Nfkbia in the hypothalamus (Fig. 3a), there was attenuated expression of Socs 3 in the mutant mice (Fig. $3 b$; genotype: $F_{(1,31)}=4.71, p=0.0379$; treatment: $F_{(1,31)}=344.69, p<0.0001$; interaction: $F_{(1,31)}=$ $13.41, p=0.0009$; LPS IL-6R $\alpha^{\Delta \text { Slcolc1 }}$ vs LPS WT: $\left.p=0.0002\right)$. Because the data above suggested that deletion of IL-6R $\alpha$ in brain endothelial cells affects signaling in the STAT3 pathway, we finally generated mice with deletion of Stat 3 in brain endothelial cells (by crossing mice with floxed Stat3 alleles with Slco1c1$C r e E R^{T 2}$ mice) and examined their febrile response to peripheral immune challenge. We found that such mice showed an attenuated temperature elevation 3-8 h after intraperitoneal injection 


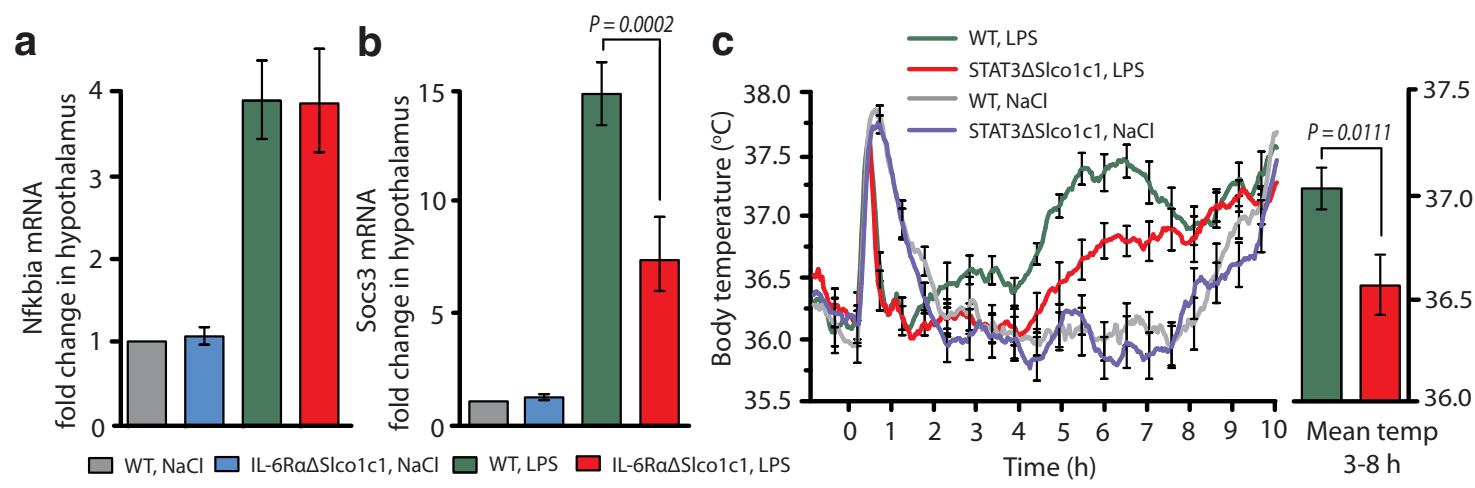

Figure 3. Induction of Cox-2 by IL-6/IL-6R $\alpha$ involves the STAT3 system. $\boldsymbol{a}, \boldsymbol{b}$, Induction of Nfkbia (a) and Socs3 (b) mRNA in the hypothalamus of IL-6R $\alpha^{\Delta \text { Slcolc1 }}$ and WT (IL-6RR ${ }^{\text {fl/fl) }}$ ) mice; $n=$ 7-10. c, Attenuated fever to $120 \mu \mathrm{g} / \mathrm{kg}$ LPS intraperitoneally in STAT3 ${ }^{\Delta \text { SIco1c1 }}$ mice; $n=10-12$.

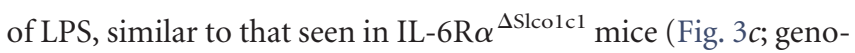
type: $F_{(1,41)}=5.94, p=0.0192$; treatment: $F_{(1,41)}=45.62, p<$ 0.0001 ; interaction: $F_{(1,41)}=3.37, p=0.0738$; LPS STAT3 ${ }^{\Delta \text { Slcolc1 }}$ vs LPS WT: $p=0.0111)$.

\section{Discussion}

The present findings show that the pyrogenic effect of IL-6 is exerted by its binding to IL- 6 receptors on brain endothelial cells, and that the ligand binding in turn leads to induced expression of the prostaglandin synthesizing enzyme Cox-2 via intracellular signaling that involves the STAT3 pathway. In contrast, IL-6 receptors on neural cells, including peripheral nerves, are not involved.

The role of IL- 6 for the generation of fever has long been obscure. On the one hand, IL-6 is critical for the febrile response, since genetic deletion of IL-6 or its neutralization blocks fever (Chai et al., 1996; Kozak et al., 1998; Cartmell et al., 2000; Nilsberth et al., 2009), but, on the other hand, IL- 6 by itself is not or only weakly pyrogenic, at least in rodents (Wang et al., 1997; Cartmell et al., 2000; Rummel et al., 2006; Nilsberth et al., 2009). Furthermore, the relation between IL- 6 and pyrogenic Cox- 2 induction has not been clear. IL-6 signaling has been suggested to be upstream, downstream, or parallel to the prostaglandin production (Kagiwada et al., 2004; Rummel et al., 2006; Nilsberth et al., 2009). Neutralizing antibodies directed against IL-6 have been shown to attenuate cerebral Cox-2 induction in response to localized peripheral inflammation (Rummel et al., 2006), but mice lacking IL- 6 show Cox- 2 induction in the brain endothelium (but no fever) in response to intraperitoneal injection of LPS (Nilsberth et al., 2009) and intravenous IL-1 injections (Kagiwada et al., 2004). The present study unequivocally shows that IL-6 is upstream of the pyrogenic Cox-2 induction and indicates that previous results from mice with global knock-out of IL- 6 might be confounded by mechanisms compensating for the mutation.

The previous findings that intraperitoneal injection of IL- 6 failed to induce Cox-2 expression in the brain, which is consistent with the absence of a pyrogenic response (Wang et al., 1997; Cartmell et al., 2000; Rummel et al., 2006; Nilsberth et al., 2009), may seem contradictory to the present findings that reduced IL- 6 receptor expression in the brain endothelium resulted in attenuated Cox- 2 expression and attenuated fever. However, it has been suggested that for IL-6 to exert a pyrogenic effect, there has to be a concomitant action of other cytokines such as IL-1. Thus, when a relatively high dose of IL-6 was injected into rats, it generated no fever; however, when injected together with a low, by itself nonpyrogenic dose of IL- $1 \beta$, fever arose (Cartmell et al., 2000). In the present experimental paradigm, in which LPS was given as immune stimulus, there is peripheral release of both IL-1 $\beta$ and IL-6 (Elander et al., 2009). Both these cytokines act on brain endothelial cells to induce Cox-2 expression and fever, but whereas the IL-1 receptor (IL-1R1) signals via the p38 MAPK and c-Jun pathway, activation of the IL-6 receptor leads to Cox- 2 expression through activation of STAT3 (present study; Rummel et al., 2006). Taking these observations together, it is likely that for a febrile response to occur several intracellular signaling pathways have to be activated by the concerted action on the brain endothelium of several peripherally released cytokines. Thus, although the present study shows that deletion in the brain endothelium of STAT3, on which IL-6 signaling is dependent (Heinrich et al., 2003), resulted in attenuated fever, activation of this signaling pathway alone is not sufficient for eliciting Cox-2 induction and prostaglandin synthesis, but also requires the activation of other Cox- 2 inducing pathways. Notably, the dependence of IL- 6 for LPS-induced fever is dose dependent. Whereas IL-6 knock-out mice show no fever to a low or moderate dose of LPS such as the one administered in the present study (Chai et al., 1996; Kozak et al., 1998; Nilsberth et al., 2009), they display a febrile response when given a very high dose of LPS (Kozak et al., 1998). These data suggest that the IL-6 signaling is critical for the febrile response to a moderate systemic immune challenge, but that it can be bypassed during severe sepsis, possibly by the redundant activation of other pyrogenic cytokines that similar to IL-6 signal via the gp130 adaptor protein (Kozak et al., 1998).

In addition to cytokine release into the blood stream, peripheral injection of LPS elicits elevated levels of cytokines, including IL-6, in the CNS (Nilsberth et al., 2009). However, with the proviso that constitutive gene deletions did not induce compensatory mechanisms in the animals, the present study demonstrates that IL-6 receptors on nerve cells do not contribute to the febrile response. This is also of interest considering the plethora of studies showing that IL-6 injected intracerebroventricularly triggers febrile responses, which can be abolished by pretreatment with Cox inhibitors (LeMay et al., 1990; Chai et al., 1996). The present findings thus imply that the temperature response seen following intracerebroventricular injection of IL-6 most likely is due to ligand binding on endothelial cells.

Because the febrile response, as well as the Cox-2 induction, was not completely blocked in mice in which in the IL-6R $\alpha$ was deleted from brain endothelial cells, it is possible that other non-neural cells in the brain, such as microglial cells, also could play a role. However, as we previously reported, the recombination in the brain endothelial cells elicited by the Slcolc1 CreER ${ }^{T 2}$ line may not be complete; when the Cox-2 gene was targeted $\sim 15 \%$ of the Cox- 2 protein induction remained (Wilhelms et al., 2014). It is conceivable that re- 
maining IL-6R $\alpha$ expression in endothelial cells accounts for the residual fever (and Cox-2 expression) seen in the present study.

It has been shown that several centrally elicited disease symptoms can be alleviated by transection of peripheral nerves, suggesting the presence of neuroimmune afferent neural pathways (Quan, 2014). For example, vagotomy was found to block LPS-induced hyperalgesia and feeding depression (Bret-Dibat et al., 1995). Furthermore, sciatic nerve transection abolished neuronal activation in a central autonomic relay nucleus, the paraventricular nucleus of the hypothalamus, which was elicited by a localized peripheral inflammation (Belevych et al., 2010). Fever has also been ascribed to the activation of peripheral nerves (Ross et al., 2003); however, in the present study there was no attenuation of the febrile response in mice with deletion of the IL-6R $\alpha$ in peripheral nerves in general (IL-6R $\alpha^{\Delta \mathrm{HtPa}}$ ) or specifically in nociceptors in primary sensory ganglia (IL-6R $\alpha^{{ }^{\mathrm{TRPV} 1}}$ ). Thus, any febrile response elicited by primary afferent signaling is not dependent on a direct effect of IL-6 on such nerves.

In conclusion, we show here that IL-6 exerts its pyrogenic effect by binding to IL-6 receptors on brain endothelial cells, which, in the context of a systemic inflammation with release of other cytokines that also act on the brain endothelium, leads to induced prostaglandin synthesis by these cells.

\section{References}

Belevych N, Buchanan K, Chen Q, Bailey M, Quan N (2010) Location-specific activation of the paraventricular nucleus of the hypothalamus by localized inflammation. Brain Behav Immun 24:1137-1147. CrossRef Medline

Bret-Dibat JL, Bluthé RM, Kent S, Kelley KW, Dantzer R (1995) Lipopolysaccharide and interleukin-1 depress food-motivated behavior in mice by a vagalmediated mechanism. Brain Behav Immun 9:242-246. CrossRef Medline

Cao C, Matsumura K, Yamagata K, Watanabe Y (1996) Endothelial cells of the rat brain vasculature express cyclooxygenase- 2 mRNA in response to systemic interleukin-1 beta: a possible site of prostaglandin synthesis responsible for fever. Brain Res 733:263-272. CrossRef Medline

Cartmell T, Poole S, Turnbull AV, Rothwell NJ, Luheshi GN (2000) Circulating interleukin-6 mediates the febrile response to localised inflammation in rats. J Physiol 526:653-661. CrossRef Medline

Cavanaugh DJ, Chesler AT, Jackson AC, Sigal YM, Yamanaka H, Grant R, O'Donnell D, Nicoll RA, Shah NM, Julius D, Basbaum AI (2011) Trpvl reporter mice reveal highly restricted brain distribution and functional expression in arteriolar smooth muscle cells. J Neurosci 31:5067-5077. CrossRef Medline

Chai Z, Gatti S, Toniatti C, Poli V, Bartfai T (1996) Interleukin (IL)-6 gene expression in the central nervous system is necessary for fever response to lipopolysaccharide or IL-1 beta: a study on IL-6-deficient mice. J Exp Med 183:311-316. CrossRef Medline

Cheng Q, Cant CA, Moll T, Hofer-Warbinek R, Wagner E, Birnstiel ML, Bach FH, de Martin R (1994) NK-kappa B subunit-specific regulation of the I kappa B alpha promoter. J Biol Chem 269:13551-13557. Medline

Ching S, Zhang H, Belevych N, He L, Lai W, Pu XA, Jaeger LB, Chen Q, Quan N (2007) Endothelial-specific knockdown of interleukin-1 (IL-1) type 1 receptor differentially alters CNS responses to IL-1 depending on its route of administration. J Neurosci 27:10476-10486. CrossRef Medline

Conti B, Tabarean I, Andrei C, Bartfai T (2004) Cytokines and fever. Front Biosci 9:1433-1449. CrossRef Medline

Elander L, Engström L, Ruud J, Mackerlova L, Jakobsson PJ, Engblom D, Nilsberth C, Blomqvist A (2009) Inducible prostaglandin E2 synthesis interacts in a temporally supplementary sequence with constitutive prostaglandin-synthesizing enzymes in creating the hypothalamicpituitary-adrenal axis response to immune challenge. J Neurosci 29: 1404-1413. CrossRef Medline

Engblom D, Saha S, Engström L, Westman M, Audoly LP, Jakobsson PJ, Blomqvist A (2003) Microsomal prostaglandin E synthase-1 is the central switch during immune-induced pyresis. Nat Neurosci 6:1137-1138. CrossRef Medline

Engström L, Ruud J, Eskilsson A, Larsson A, Mackerlova L, Kugelberg U, Qian H, Vasilache AM, Larsson P, Engblom D, Sigvardsson M, Jönsson JI, Blomqvist A (2012) Lipopolysaccharide-induced fever depends on prostaglandin E2 production specifically in brain endothelial cells. Endocrinology 153:4849-4861. CrossRef Medline

Engström Ruud L, Wilhelms DB, Eskilsson A, Vasilache AM, Elander L, Engblom D, Blomqvist A (2013) Acetaminophen reduces lipopolysaccharide-induced fever by inhibiting cyclooxygenase-2. Neuropharmacology 71:124-129. CrossRef Medline

Gadient RA, Otten U (1996) Postnatal expression of interleukin-6 (IL-6) and IL-6 receptor (IL-6R) mRNAs in rat sympathetic and sensory ganglia. Brain Res 724:41-46. CrossRef Medline

Heinrich PC, Behrmann I, Haan S, Hermanns HM, Müller-Newen G, Schaper F (2003) Principles of interleukin (IL)-6-type cytokine signalling and its regulation. Biochem J 374:1-20. CrossRef Medline

Kagiwada K, Chida D, Sakatani T, Asano M, Nambu A, Kakuta S, Iwakura Y (2004) Interleukin (IL)-6, but not IL-1, induction in the brain downstream of cyclooxygenase- 2 is essential for the induction of febrile response against peripheral IL-1 \{alpha\}. Endocrinology 145:5044-5048. CrossRef Medline

Kluger MJ (1991) Fever: role of pyrogens and cryogens. Physiol Rev 71:93127. Medline

Kozak W, Kluger MJ, Soszynski D, Conn CA, Rudolph K, Leon LR, Zheng H (1998) IL-6 and IL-1 beta in fever. Studies using cytokine-deficient (knockout) mice. Ann N Y Acad Sci 856:33-47. CrossRef Medline

Lazarus M, Yoshida K, Coppari R, Bass CE, Mochizuki T, Lowell BB, Saper CB (2007) EP3 prostaglandin receptors in the median preoptic nucleus are critical for fever responses. Nat Neurosci 10:1131-1133. CrossRef Medline

LeMay LG, Vander AJ, Kluger MJ (1990) Role of interleukin 6 in fever in rats. Am J Physiol 258:R798-R803. Medline

Li S, Wang Y, Matsumura K, Ballou LR, Morham SG, Blatteis CM (1999) The febrile response to lipopolysaccharide is blocked in cyclooxygenase$2(-/-)$, but not in cyclooxygenase-1(-/-) mice. Brain Res 825:86-94. CrossRef Medline

Nilsberth C, Elander L, Hamzic N, Norell M, Lönn J, Engström L, Blomqvist A (2009) The role of interleukin-6 in lipopolysaccharide-induced fever by mechanisms independent of prostaglandin E2. Endocrinology 150: 1850-1860. CrossRef Medline

Pietri T, Eder O, Blanche M, Thiery JP, Dufour S (2003) The human tissue plasminogen activator-Cre mouse: a new tool for targeting specifically neural crest cells and their derivatives in vivo. Dev Biol 259:176-187. CrossRef Medline

Quan N (2014) In-depth conversation: spectrum and kinetics of neuroimmune afferent pathways. Brain Behav Immun 40:1-8. CrossRef Medline

Reyes TM, Walker JR, DeCino C, Hogenesch JB, Sawchenko PE (2003) Categorically distinct acute stressors elicit dissimilar transcriptional profiles in the paraventricular nucleus of the hypothalamus. J Neurosci 23:5607-5616. Medline

Ridder DA, Lang M-F, Salinin S, Röderer JP, Struss M, Maser-Gluth C, Schwaninger M (2011) TAK1 in brain endothelial cells mediates fever and lethargy. J Exp Med 208:2615-2623. CrossRef Medline

Ross G, Hübschle T, Pehl U, Braun HA, Voigt K, Gerstberger R, Roth J (2003) Fever induction by localized subcutaneous inflammation in guinea pigs: the role of cytokines and prostaglandins. J Appl Physiol 94: 1395-1402. Medline

Rudaya AY, Steiner AA, Robbins JR, Dragic AS, Romanovsky AA (2005) Thermoregulatory responses to lipopolysaccharide in the mouse: dependence on the dose and ambient temperature. Am J Physiol Regul Integr Comp Physiol 289:R1244-R1252. CrossRef Medline

Rummel C, Sachot C, Poole S, Luheshi GN (2006) Circulating interleukin-6 induces fever through a STAT3-linked activation of COX-2 in the brain. Am J Physiol Regul Integr Comp Physiol 291:R1316-R1326. CrossRef Medline

Starr R, Willson TA, Viney EM, Murray LJ, Rayner JR, Jenkins BJ, Gonda TJ, AlexanderWS, MetcalfD, Nicola NA, Hilton DJ (1997) A family of cytokine-inducible inhibitors of signalling. Nature 387:917-921. CrossRef Medline

Vallières L, Rivest S (1997) Regulation of the genes encoding interleukin-6, its receptor, and gp130 in the rat brain in response to the immune activator lipopolysaccharide and the proinflammatory cytokine interleukin1beta. J Neurochem 69:1668-1683. CrossRef Medline

Wang J, Ando T, Dunn AJ (1997) Effect of homologous interleukin-1, interleukin- 6 and tumor necrosis factor-alpha on the core body temperature of mice. Neuroimmunomodulation 4:230-236. Medline

Wilhelms DB, Kirilov M, Mirrasekhian E, Eskilsson A, Kugelberg UÖ, Klar C, Ridder DA, Herschman HR, Schwaninger M, Blomqvist A, Engblom D (2014) Deletion of prostaglandin E2 synthesizing enzymes in brain endothelial cells attenuates inflammatory fever. J Neurosci 34:11684-11690. CrossRef Medline 